\title{
PENYULUHAN KESEHATAN RUTIN PUSKESMAS UNTUK MENCEGAH SEKOLAH DASAR DENGAN KEJADIAN DBD DI KOTA MADIUN TAHUN 2017
}

\section{THE REGULAR HEALTH COUNSELING BY THE HEALTH SERVICE CENTER FOR PREVENTING DHF INCIDENCE IN ELEMENTARY SCHOOL IN MADIUN CITY IN 2017}

\author{
Puri Ratna Kartini ${ }^{1)}$,Santi Martini ${ }^{2)}$,Shrimarti Rukmini Devy ${ }^{3)}$ \\ ${ }^{1)}$ Progam Studi Farmasi Fakultas Ilmu Kesehatan dan Sain Universitas PGRI Madiun,Indonesia \\ 2) Departemen Epidemiologi Fakultas Kesehatan Masyarakat Universitas Airlangga Surabaya \\ 3) Departemen Pendidikan Kesehatan Dan Ilmu Perilaku Fakultas Kesehatan Masyarakat \\ Universitas Airlangga Surabaya \\ puri@unipma.ac.id
}

\begin{abstract}
ABSTRAK
Demam Berdarah Dengue (DBD) masih menjadi masalah kesehatan di Kota Madiun. Berdasarkan data dari Dinas Kesehatan Kota Madiun (2011-2015) terjadi peningkatan kejadian DBD yang signifikan selama 5 tahun terakhir. Sebagian besar penderita DBD di Kota Madiun adalah anak usia Sekolah Dasar. Hal ini mengindikasikan bahwa program penanggulangan DBD terutama di sekolah dasar di Kota Madiun masih kurang efektif terutama kegiatan penyuluhan rutin kesehatan oleh Puskesmas terkait dengan PSN melalui kegiatan 3M plus. Penelitian ini bertujuan untuk menganalisis pengaruh penyuluhan kesehatan rutin Puskesmas terhadap kejadian DBD di Sekolah Dasar di Kota Madiun. Penelitian ini merupakan penelitian observasional analitik dengan desain case control. Populasi dalam penelitian ini terbagi dalam 2 kelompok, yaitu populasi kasus (SD dengan kejadian DBD) sebanyak 33 SD dan populasi kontrol (SD tidak dengan kejadian DBD).sebanyak 51 SD. Sampel dalam penelitian ini terbagi dalam 2 kelompok, yaitu sampel kasus (SD dengan kejadian DBD yang terpilih) sebanyak 30 SD dan sampel kontrol (SD tidak dengan kejadian DBD) sebanyak 30 SD. Teknik pengambil sampel adalah dengan Simple Random Sampling. Dari hasil uji analisis diperoleh hasil bahwa penyuluhan kesehatan rutin Puskesmas berpengaruh terhadap kejadian DBD di Sekolah Dasar di Kota Madiun ( $p=$ 0,001).
\end{abstract}

Kata kunci : DBD, Madiun, Penyuluhan Kesehatan, Sekolah Dasar

\section{ABSTRACT}

Dengue Hemorrhagic Fever (DHF) is still a health problem in Madiun City. Based on data from the Madiun City Health Office (2011-2015) there has been a significant increase in DHF incidence over the past 5 years. Most DHF patients in Madiun City are elementary school children. This indicates that the program of DHF especially in primary school in Madiun is still less effective, especially routine health counseling by the heakth service centre related to PSN through $3 M$ plus activities. This study aims to analyze the influence of routine health counseling by the health service centre to the incidence of DHF in Primary School in Madiun City. This research is an observational analytic research with case control design. The population in this study is divided into 2 groups, namely the case population (SD with DHF incidence) of 33 SD and control population (SD not with DHF incidence). The sample in this study is divided into 2 groups, namely the case sample (SD with selected DHF incidence) of 30 SD and control sample (SD not with DHF 


\section{Journal of Pharmaceutical Science and Medical Research \\ ISSN 2614-4840 (print) 2614-6118 (online)}

\section{Vol. 1 No. 1 Tahun 2018}

incidence) of 30 SD. Sampling technique is by Simple Random Sampling. From the result of the analysis test, it is found out that the routine health education of Puskesmas has an effect on the occurrence of DHF in Primary School in Madiun City $(p=0,001)$.

Keywords: DHF, Madiun, Health Counseling, Elementary School

\section{PENDAHULUAN}

Penyakit Demam Berdarah Dengue (DBD) merupakan salah satu masalah kesehatan di Indonesia. Berdasarkan data World Health Organization (WHO), terhitung sejak tahun 1968 hingga tahun 2011, Indonesia merupakan negara dengan kasus DBD tertinggi di Asia Tenggara (WHO, 2012). Trend penyakit DBD di Indonesia tergolong fluktuatif, namun memiliki kecenderungan untuk meningkat sehingga pada tahun 2015, angka IR penyakit DBD di Indonesia telah melampaui target

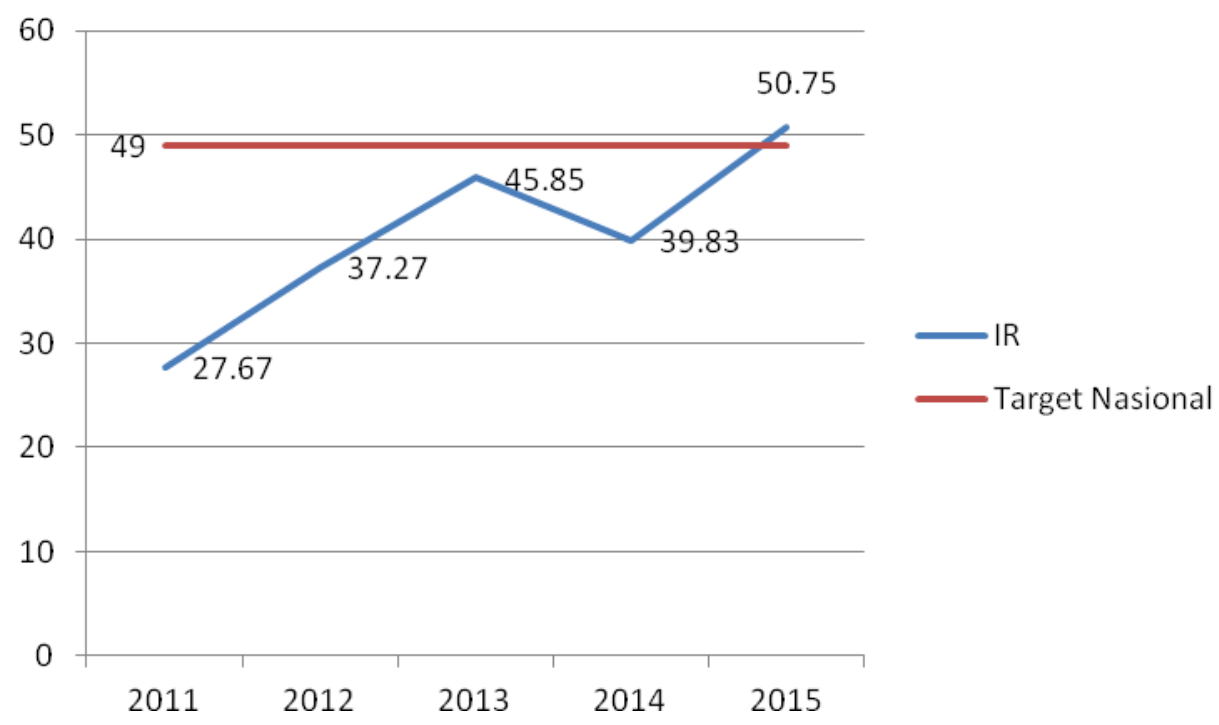

Sumber : Profil Kesehatan RI, 2015 dalam Kartini, 2017

Gambar 1. Incidence Rate Penyakit DBD di Indonesia Tahun 2011-2015

Kota Madiun merupakan daerah endemik DBD. Berdasarkan data dari seksi P2P Dinkes Kota Madiun, menyebutkan terdapat peningkatan kasus DBD pada 5 tahun terakhir. Pada tahun 2015, jumlah
Nasional (<49) (Kartini, 2017). Berdasarkan laporan Balai Penelitian dan Pengembangan Kementerian Kesehatan Republik Indonesia, tercatat kasus DBD di Indonesia pada tahun 2015 sebanyak 129.650 kasus, meningkat dari 99.499 kasus pada tahun 2014 (Kemenkes RI, 2015 dalam Kartini 2017). Berikut ini angka kejadian DBD Nasional per 100.000 penduduk selama 5 tahun berturut-turut: 
Journal of Pharmaceutical Science and Medical Research

ISSN 2614-4840 (print) 2614-6118 (online)

Vol. 1 No. 1 Tahun 2018

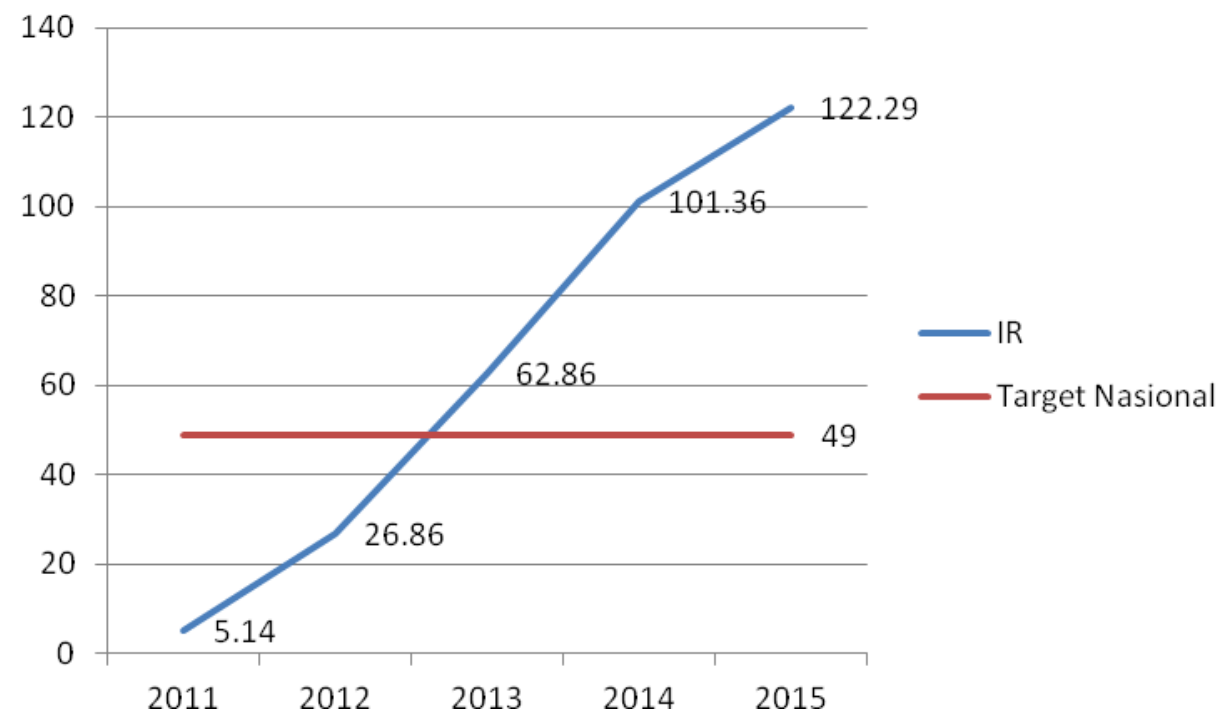

Sumber : Seksi P2P Dinkes Kota Madiun, 2015 dalam Kartini, 2017

Gambar 2. Incidence Rate Penyakit DBD di Kota Madiun Tahun 20112015

Berdasarkan laporan seksi $\quad 42 \%$ atau 46 kasus pada tahun 2013, P2P Dinas Kesehatan Kota Madiun, $\quad 35 \%$ atau 62 kasus pada tahun 2014 penderita DBD di Kota Madiun (Kartini, 2017). Berikut ini gambaran didominasi oleh kelompok usia anak distribusi kejadian DBD berdasarkan sekolah dasar usia 7-12 tahun selama kelompok umur di Kota Madiun 4 tahun berturut-turut, yaitu sebesar tahun 2015:

$49 \%$ atau 23 kasus pada tahun 2012,

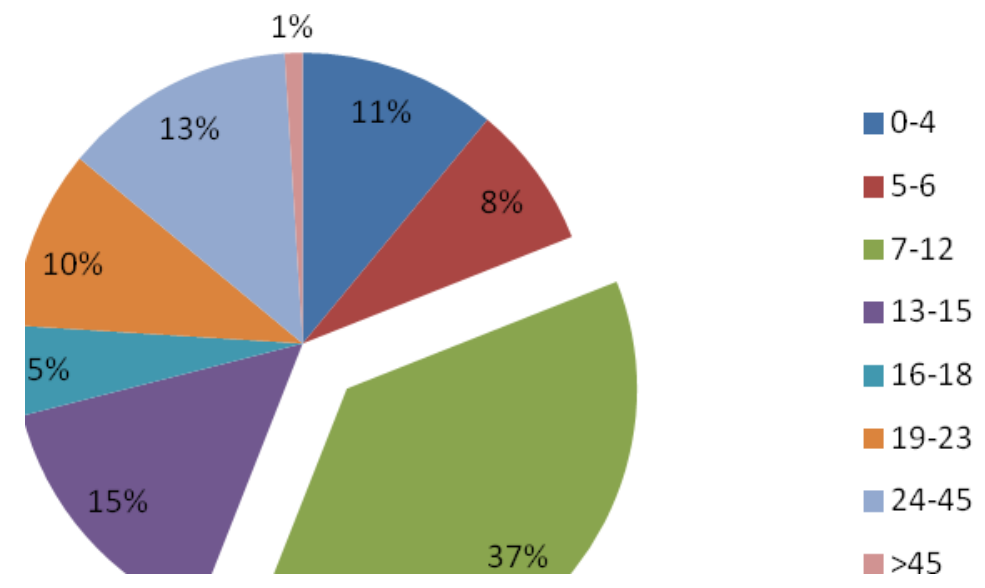

Sumber: Seksi P2P Dinkes Kota Madiun Tahun 2015 dalam Kartini, 2017

Gambar 3. Distribusi Kasus DBD Berdasarkan Kelompok Umur di Kota Madiun Pada Tahun 2015 


\section{Journal of Pharmaceutical Science and Medical Research ISSN 2614-4840 (print) 2614-6118 (online)}

Vol. 1 No. 1 Tahun 2018

Gambar 3 menunjukkan bahwa penderita DBD di Kota Madiun pada tahun 2015 kembali didominasi oleh kelompok anak usia sekolah dasar, yaitu sebesar 37\% atau 80 kasus. Djunaedi dalam Rusnaini (2015) menyebutkan bahwa anak usia sekolah dasar merupakan kelompok usia yang aktif beraktivitas di luar rumah. Sebagian besar waktu anak usia sekolah dasar adalah berada di lingkungan sekolah terutama pada pagi dan sore hari bersamaan dengan kebiasaan vektor DBD menggigit, yaitu antara pukul 08.00-13.00 dan antara pukul 15.00- 17.00 (Kartini, 2017). Murid sekolah dapat berasal dari berbagai wilayah tempat tinggal yang memungkinkan membawa jenisjenis virus dengue yang berbeda-beda, sehingga lingkungan sekolah merupakan tempat yang rawan bagi penularan penyakit DBD pada anak usia sekolah dasar (Depkes RI dalam Andini, 2013).

Angka kejadian DBD yang tinggi di Kota Madiun menunjukkan bahwa program pengendalian DBD terutama yang ada di sekolah Madiun masih lemah. Sebab, menurut Kemenkes RI (2010) tingginya angka kejadian DBD salah satunya adalah karena lemahnya upaya program pengendalian DBD yang ada (Kartini, 2017). Program penanggulangan DBD yang perlu untuk dilaksanakan dengan optimal misalnya penyuluhan atau sosialisasi PSN melalui 3M plus di lingkungan sekolah. Hal ini karena DBD merupakan penyakit berbasis perilaku manusia, sehingga dengan adanya penyuluhan PSN diharapkan mampu meningkatkan pengetahuan masyarakat tentang pencegahan penyakit menular ini.
Penyuluhan kesehatan oleh Puskesmas di sekolah dalam rangka mencegah penyakit DBD adalah upaya Puskesmas untuk meningkatkan kemampuan siswa, guru, kepala sekolah dan warga sekolah lainnya agar dapat mandiri dalam meningkatkan derajat kesehatan melalui upaya pencegahan DBD sebagai salah satu masalah kesehatan dan mengembangkan upaya kesehatan bersumber daya masyarakat, melalui pembelajaran dari, oleh, untuk dan bersama mereka, sesuai sosial budaya mereka, serta didukung kebijakan publik yang berwawasan kesehatan (Kemenkes RI, 2011 dalam Kartini, 2017).

Penyuluhan kesehatan dalam rangka pencegahan DBD yang dilakukan oleh Puskesmas di sekolah misalnya berupa penyuluhan dan penggerakan masyarakat sekolah untuk PSN, penyuluhan/informasi tentang DBD dan pencegahannya dilakukan melalui jalur- jalur informasi yang ada, yaitu melalui UKS sebagai unit pelaksana promosi kesehatan di sekolah dan dokter cilik (Depkes, 1998 dalam Kartini 2017). Studi yang dilakukan oleh Nathan dkk (2004) menunjukkan bahwa anak sekolah adalah saluran promosi kesehatan yang sangat efektif untuk memberantas vektor penyakit di lima negara di kawasan Amerika Tengah dan Selatan (Kartini, 2017).

Berdasarkan hal tersebut, penelitian ini bertujuan untuk mengetahui pengaruh penyuluhan kesehatan rutin oleh Puskesmas terhadap kejadian DBD di Sekolah Dasar di Kota Madiun. 


\section{Journal of Pharmaceutical Science and Medical Research \\ ISSN 2614-4840 (print) 2614-6118 (online)}

Vol. 1 No. 1 Tahun 2018

\section{METODE}

Penelitian ini merupakan penelitian observasional analitik, yaitu penelitian yang hanya melakukan observasi atau pengamatan tanpa memberikan perlakuan pada objek penelitian dengan menggunakan desain case control untuk mengetahui pengaruh penyuluhan kesehatan rutin Puskesmas terhadap kejadian DBD di sekolah dasar. Menurut Candra (2013), desain case control digunakan untuk mengetahui faktor risiko atau masalah kesehatan yang diduga memiliki hubungan erat dengan penyakit yang terjadi di masyarakat secara retrospektif.

Maka, penelitian ini dimulai setelah munculnya penyakit/masalah kesehatan yaitu kejadian DBD di sekolah dasar. Kemudian ditelusuri ke belakang penyebab atau paparan yang dapat menimbulkan penyakit tersebut dalam hal ini adalah penuluhan kesehatan rutin Puskesmas dengan membandingkan diantara kelompok studi, yaitu kelompok kasus (SD yang terdapat siswa yang menderita DBD) dengan kelompok kontrol (SD yang tidak terdapat siswa yang menderita DBD).

Penelitian ini dilaksanakan mulai dari bulan Januari sampai dengan bulan Desember 2016. Lokasi penelitian ini adalah di wilayah kerja Dinas Kesehatan Kota Madiun, Provinsi Jawa Timur. Populasi dalam penelitian ini dibagi menjadi 2, yaitu:

1. Populasi kasus adalah seluruh SD yang terdapat siswa penderita DBD pada bulan Januari-Oktober 2016, yaitu sebanyak 33 SD.

2. Populasi kontrol adalah seluruh SD yang tidak terdapat siswa penderita DBD pada bulan Januari-Oktober 2016, yaitu sebanyak 51 SD.

Sampel dalam penelitian ini dibagi menjadi dua, yaitu:

1. Sampel kasus adalah SD yang terdapat siswa penderita DBD pada bulan Januari-Oktober 2016 yang terpilih.

2. Sampel kontrol adalah SD yang tidak terdapat siswa penderita DBD pada bulan Januari-Oktober 2016 yang terpilih.

Besar sampel ditentukan dengan memperhatikan nilai odds ratio $(O R)$ hasil penelitian sebelumnya. Nilai $O R$ pada penelitian sebelumnya dapat dilihat pada Tabel 1 di bawah ini.

Tabel 1. Rekapitulasi Nilai OR pada Penelitian Sebelumnya

\begin{tabular}{lllll}
\hline Variabel & Nilai P & OR & $\mathbf{9 5 \%}$ CI & Keterangan \\
\hline $\begin{array}{l}\text { Keberadaan jentik nyamuk } \\
\text { pada TPA }\end{array}$ & 0,050 & 5,586 & $1,118-27,900$ & $\begin{array}{l}\text { Ada } \\
\text { hubungan }\end{array}$ \\
\hline
\end{tabular}

Sumber : Tamza (2013).

Untuk menentukan besar
sampel dalam penelitian ini digunakan rumus besar sampel (Lwanga S. K. \& Lemeshow, S., 1991) :

Hypothesis test an odds ratio :

Dimana: $\mathrm{P} 1=\frac{(\mathrm{OR}) \mathrm{P} 2}{(\mathrm{OR}) \mathrm{P} 2+(1-\mathrm{P} 2)}$ 


\section{Journal of Pharmaceutical Science and Medical Research \\ ISSN 2614-4840 (print) 2614-6118 (online)}

Vol. 1 No. 1 Tahun 2018

Setelah dilakukan perhitungan sampel besar sampel menggunakan perhitungan besar sampel (Size Determination In Health Studies) oleh Lwanga dan Lemeshow, diperoleh sampel sebesar 30 sekolah. Besar sampel kontrol ditentukan dengan perbandingan $1: 1, \quad$ dengan pertimbangan jumlah populasi kasus dapat memenuhi besar sampel yang diperlukan dalam penelitian ini. Sehingga besar sampel secara keseluruhan adalah 60 sekolah.

Teknik pengambilan sampel yang digunakan dalam penelitian ini adalah secara acak sederhana (simple random sampling) yang dilakukan terlebih dahulu dengan menyusun kerangka sampling. Pertama dengan memilah seluruh SD yang terdapat siswa penderita DBD yang diperoleh dari Formulir Penyelidikan Epidemiologi pada Dinas Kesehatan Kota Madiun, dan seluruh SD yang tidak terdapat siswa penderita DBD yang diperoleh dari Dinas Pendidikan dan Kebudayaan Kota Madiun. Kemudian menyusun daftar SD mulai dari 1 hingga total keseluruhan populasi pada masing-masing kelompok. Terakhir, dari daftar tersebut dilakukan pemilihan secara acak sederhana (simple random sampling) hingga memenuhi besar sampel yang dibutuhkan.

Pengumpulan data primer
dilakukan dengan wawancara
terhadap responden menggunakan
instrumen penelitian berupa kuesioner
untuk faktor risiko perilaku organisasi
sekolah dan pelayanan kesehatan,
serta lembar observasional untuk
melakukan pengamatan/observasi
terhadap faktor risiko lingkungan
sekolah. Pengumpulan data dilakukan

setelah responden diberi Penjelasan Sebelum Persetujuan (PSP) dan menandatangani Informed Consent.

Prosedur Pengumpulan Data dilakukan dengan:

a.Data primer yakni data yang diperoleh secara langsung dengan melakukan wawancara terhadap Kepala Sekolah dan guru UKS melalui kuesioner atau pertanyaan yang telah disusun. Waktu yang dibutuhkan selama melakukan observasi dan wawancara \pm 40 menit.

b. Data sekunder yakni data kasus DBD diperoleh dari KDRS di Dinas Kesehatan, data asal sekolah siswa SD penderita DBD diperoleh dari Formulir Penyelidikan Epidemiologi di Dinas Kesehatan dan data SD yang tidak terdapat siswa penderita DBD diperoleh dari Dinas Pendidikan dan Kebudayaan.

Kasus DBD dalam penelitian ini adalah anak usia SD (7-12 tahun) yang sudah terdiagnosis positif menderita DBD oleh dokter berdasarkan berbagai pemeriksaan dan uji laboratorium. Kasus DBD yang digunakan adalah yang ditemukan tanggal 1 Januari - 31 Oktober 2016.

\section{HASIL DAN PEMBAHASAN}

Penyuluhan kesehatan rutin Puskesmas dalam penelitian ini adalah penyuluhan yang diberikan oleh petugas kesehatan Puskesmas atau kader jumantik kepada guru UKS dan petugas kebersihan sekolah pada saat melaksanakan PJB setiap 3 bulan sekali atau setiap 6 bulan sekali pada saat musim penghujan . Guru UKS dan petugas kebersihan sekolah 


\section{Journal of Pharmaceutical Science and Medical Research \\ ISSN 2614-4840 (print) 2614-6118 (online)}

Vol. 1 No. 1 Tahun 2018

diberikan informasi dan saran terkait melaksanakan PSN DBD melalui pencegahan DBD berdasarkan hasil pemantauan jenatik yang dilaksanakan di sekolah yang bersangkutan. Dari penyuluhan kegiatan 3M plus. Distribusi penyuluhan rutin Puskesmas terhadap SD dengan kejadian DBD disajikan tersebut diharapkan dapat memotivasi dalam tabel berikut ini:

Tabel 2. Distribusi Penyuluhan Kesehatan Rutin Puskesmas Terhadap SD Dengan Kejadian DBD

\begin{tabular}{cccc}
\hline \multirow{2}{*}{$\begin{array}{c}\text { Penyuluhan kesehatan } \\
\text { rutin Puskesmas }\end{array}$} & \multicolumn{2}{c}{ SD Dengan Kejadian DBD } & \multirow{2}{*}{ Total } \\
\cline { 2 - 3 } & Ya & Tidak & \\
\hline Tidak rutin & $21(70 \%)$ & $8(26,7 \% 0$ & $29(48,3 \%)$ \\
\hline Rutin & $9(30 \% 0$ & $22(73,3 \%)$ & $31(51,7 \%)$ \\
\hline Total & $30(100 \%)$ & $30(100 \%)$ & $60(100 \%)$ \\
\hline
\end{tabular}

Dari Tabel 2 didapatkan bahwa SD tidak dengan kejadian DBD yang mendapatkan penyuluhan rutin dari Puskesmas jumlahnya lebih banyak $(73,3 \%)$ daripada SD dengan kejadian DBD (30\%). Menurut keterangan beberapa responden dari SD dengan kejadian DBD, penyuluhan terkait DBD dari Puskesmas hanya diberikan kepada siswa pemantau jentik setahun sekali pada saat pelatihan adiwiyata atau dokter kecil untuk selanjutnya disampaikan kepada siswa lain, namun hal tersebut juga tidak berjalan. Ini berarti bahwa penyuluhan terkait pencegahan DBD tidak tersampaikan kepada warga sekolah secara keseluruhan. Berikut hasil anaisis menggunakan uji regresi logistik sederhana:

Tabel 3. Hasil Analisis Regresi Logistik Sederhana Pengaruh Penyuluhan Kesehatan Rutin Puskesmas Terhadap Kejadian DBD di Sekolah Dasar di Kota Madiun Tahun 2016

\begin{tabular}{ccc}
\hline Variabel & $\boldsymbol{p}$ Value & Kesimpulan \\
\hline Penyuluhan kesehatan rutin Puskesmas & 0,001 & Signifikan \\
\hline
\end{tabular}

Penyuluhan adalah suatu upaya perubahan perilaku manusia yang dilakukan melalui pendekatan edukatif yang bertujuan untuk meningkatkan pengetahuan, sikap serta perilaku individu, maupun kelompok dalam masyarakat. Penyuluhan kesehatan adalah gabungan berbagai kegiatan dan kesempatan yang berlandaskan prinsip-prinsip belajar untuk mencapai suatu keadaan, dimana individu, keluarga, kelompok atau masyarakat secara keseluruhan ingin hidup sehat, tahu bagaimana caranya dan melakukan apa yang biasa dilakukan, secara perseorangan maupun secara kelompok dengan meminta pertolongan (Effendy, 2003 dalam Kartini, 2017). Berdasarkan definisi tersebut, maka penyuluhan kesehatan rutin Puskesmas yang diberikan kepada sekolah-sekolah yang menjadi binaan Puskesmas 


\section{Journal of Pharmaceutical Science and Medical Research \\ ISSN 2614-4840 (print) 2614-6118 (online)}

Vol. 1 No. 1 Tahun 2018

merupakan hal yang mutlak diperlukan guna menciptakan perilaku pencegahan terhadap penyakit DBD di lingkungan sekolah.

Dalam penelitian ini diperoleh kesimpulan bahwa penyuluhan kesehatan rutin Puskesmas memiliki pengaruh terhadap kejadian DBD di sekolah dasar. Penyuluhan kesehatan rutin dalam penelitian ini adalah penyuluhan yang terkait dengan pencegahan penyakit DBD yang idealnya diberikan pada saat petugas kesehatan atau jumantik melakukan PJB di sekolah setiap 3 bulan sekali atau melaksanakan kunjungan pada saat musim penghujan, dimana hasil penemuan di lapangan menunjukkan bahwa SD tidak dengan kejadian DBD sebagian besar mendapatkan penyuluhan kesehatan rutin dari Puskesmas, sedangkan sebagian besar SD dengan kejadian DBD tidak mendapatkan penyuluhan kesehatan rutin dari Puskesmas. Berdasarkan keterangan dari para responden, hal ini disebabkan karena penyuluhan tentang pencegahan DBD hanya diberikan oleh Puskesmas atau Dinkes kepada dokter cilik yang merangkap sebagai kader jumantik anak sekolah setiap setahun sekali pada saat pelatihan adiwiyata untuk kemudian disampaikan kepada siswa lain di sekolahnya. Namun, pada kenyataannya hal tersebut tidak terealisir. Sehingga penyuluhan kesehatan tersebut tidak dapat menjangkau warga sekolah secara keseluruhan.

Hasil dari penelitian ini sesuai dengan penelitian sebelumnya, yaitu studi yang dilakukan oleh Soeparmanto (2006) dalam Kartini (2017), bahwa keaktifan petugas dalam memberikan penyuluhan untuk memotivasi warga sekolah dalam melaksanakan PSN DBD memiliki pengaruh besar dalam mencegah penularan DBD di lingkungan sekolah. Dengan kunjungan yang rutin disertai dengan penyuluhan diharapkan sekolah dapat melakukan PSN DBD secara teratur dan terusmenerus (Depkes RI, 2010 dalam Kartini 2017).

\section{KESIMPULAN}

Berdasarkan hasil penelitian ini, dapat ditarik kesimpulan bahwa penyuluhan kesehatan rutin Puskesmas merupakan faktor risiko kejadian DBD di Sekolah Dasar Kota Madiun Tahun 2016.

\section{DAFTAR PUSTAKA}

Dinkes Kota Madiun. 2011-2015. Profil Kesehatan Kota Madiun. Madiun: Dinkes Kota Madiun.

Kartini, Puri Ratna. 2017. Indeks Prediktif Kejadian Demam Berdarah Dengue di Sekolah Dasar di Kota Madiun Tahun 2016. Tesis. Surabaya: Universitas Airlangga.

Tamza, Riza Berdian., Suhartono., Dharminto. 2013. Hubungan Faktor Lingkungan Dan Perilaku Dengan Kejadian Demam Berdarah Dengue (DBD) di Wilayah Kelurahan Perumnas Way Halim Kota Bandar Lampung. Jurnal Kesehatan Masyarakat, Volume 2, Nomor 2.

http://s3.amazonaws.com/acad emia.edu.documents/3331400 
Journal of Pharmaceutical Science and Medical Research ISSN 2614-4840 (print) 2614-6118 (online)

Vol. 1 No. 1 Tahun 2018

7/jurnal_indd.pdf?AWSAcces sKeyId=AKIAJ56TQJRTWS

MTNPEA\&Expires $=1472912$

$427 \&$ Signature $=$ FoHMDwrW SFfhcILBq\%2BRI\%2BzYXk $\mathrm{xQ} \% 3 \mathrm{D} \&$ response-contentdisposition=inline $\% 3 \mathrm{~B} \% 20$ fil ename\%3DHUBUNGAN_FA KTOR_LINGKUNGAN_DA N_PERILAKU.pdf (Diakses September 2016).

WHO. 2012. Dengue and Severe Dengue.

http://www.who.int/mediacent re/factsheets/fs117/en/

(diakses Mei 2016) 